\title{
Transformational Linguistics and the Implication Towards Second Language Learning
}

\author{
Noor Khasanah
}

State Islamic Senior High School (MAN) of Pati

Jl. Panglima Sudirman Km.3 Pati, Central Java, Indonesia

imam_sta@yahoo.com

\section{Abstract}

The essence of Chomsky's approach to language is the claim that there are linguistic universals in domain of syntax. He felt confident to show that syntax can be defined for any given language. For Chomsky, the nature of such mental representations is largely innate, so if a grammatical theory has explanatory adequacy it must be able to explain the various grammatical nuances of the languages of the world as relatively minor variations in the universal pattern of human language.

In teaching English as L2, therefore knowing syntax and grammar of the language is important. Transformational Generative Grammar gives adequate elaboration in understanding them. Thus, the learners are expected to be able to avoid such ambiguity in interpreting the deep structure of a sentence since ambiguity will lead other people as the listeners or hearers of the speakers to misinterpret either consciously or unconsciously.

Keywords: Surface Structure, Deep Structure, Constituent, Transformation

\begin{abstract}
Abstrak
Dalam pengajaran bahasa Inggris sebagai bahasa kedua, pemahaman mengenai sintaks dan tata bahasa sangatlah penting. Dalam hal ini, Tata Bahasa Generatif Transformatif telah memberikan penjabaran yang cukup dalam memahami keduanya. Oleh karena itu, para pelajar diharapkan dapat menghindari berbagai macam ambiguitas dalam menterjemahkan struktur kalimat secara mendalam mengingat keambiguan tersebutdapat menyebabkan orang lain sebagai pendengar dari empunya bicara salah dalam memahami apa yang diucapkan baik secara sadar maupun tidak tidak sadar.
\end{abstract}

Kata Kunci: Struktur Dasar,Struktur Mendalam,Konstituen,Transformasi 


\section{Introduction}

Noam Chomsky is said to have brought about a revolution in linguistics. He took linguistics beside mathematics and philosophy. In the early 1950s, he pursued his research work as a Junior Fellow in Philosophy at Harvard, where Roman Jakobson was teaching, and in 1955 Chomsky was given a teaching post at the Massachusetts Institute of technology. Jakobson believed that the different phonological structures found in the languages of underlying system. Although it is only in the level of phonological universal, he however believed that the approach would be applicable also to other level of linguistic structures (Sampson, 1980: 131).

The essence of Chomsky's approach to language is the claim that there are linguistic universals in domain of syntax; and he develops that hypothesis that his theory will deeper and richer than Jakobson's theory. Therefore, Chomsky felt confident to show that syntax can be defined for any given language.

On the other hand, Saussure said that syntax was not even part of langue, the structure of a given language, however, it was a matter of parole, the fact remained that they had not overall succeeded in finding ways to incorporate syntactic analysis into the scientific study of language.

Radford (1997) states that grammar is traditionally subdivided into two different but inter-related areas of study - morphology and syntax. Morphology is the study of how words are formed out of smaller units (traditionally called morphemes) and so addresses questions as 'What are the various components parts(morphemes) of a word like antidisabilitory, and what kinds of principles determine the ways in which the parts are combined together to form the whole?'. Syntax is concerned with the ways in which words can be combined together to form phrases and sentences, and so addresses 
questions like "Why is it OK in English to say Whom did John talk to?, but not OK to say *Whom did John talk and? (an asterik in front of an expression means that it's ungrammatical). In terms of the traditional tradition division of grammar into morphology and syntax, we can say that morphology studies the formation and interpretation of words, whereas syntax is concerned with the formation and interpretation of phrases and sentences.

In similar intention, Jacobs and Rosenbaum (1976: 3) presented that particular language has its mysteries of a natural phenomenon which lead a person to be capable of distinguishing the sentences of his own language from any other languages over the world. This is represented in the strings of words which are meaningful (said as sentence) and meaningless (is only a kind of words order with no meaning). Let's see the following strings of words.

The following strings are English sentences:

a. An increase in population of Indonesia is high enough b. My special girl friend gave a present on $\mathrm{m}$ birthday.

c. Are you looking for Jack?

d. What a silly idea!

Suppose the word order of these strings are reversed:

e. *increase is an of enough population in Indonesia high $\mathrm{f}$. * special my gave girl a my on friend present birthday. g. *Jack you looking are for?

h. *a what idea silly!

Every speakers of English surely know that the last there strings are not English sentences, even they consist of some English words. An asterisk is placed before the string, which is semantically and syntactically ill formed. It leads to a question how they are able to say that a, b, and c are English sentences and c, d, e are not. How do they get the knowledge? Is it a kind of conscious or unconscious process? Within the phenomenon above, it is therefore necessary to develop language study to get further understanding 
how a person able to comprehend and interpret particular language and even to use the language in proper real situation.

\section{The theory of language study}

Linguistics is the study of language. It is fundamental to study language because language is the mirror of mind we might hope to reach better understanding of how the human mind produces and processes language.

Chomsky (Radford, 1997: 1-2) said that there are three inter- related theories which any detailed study of language ultimately seeks to develop, namely: (1) Theory of language structure will concern itself with what are defining structural properties of natural languages (human Languages); (2) Theory of language acquisition with the question of how children acquire their native languages; and (3) Theory of language use with the question of how linguistic and nonlinguistic knowledge interact in speech comprehension and production

Of the three, the task of (1) is logically prior to the other two, since only if we first know what "language" is can we develop theories about how it acquired and used. Therefore, most of Chomsky's works attempt to develop the (1). Thus, it can be concluded that to be able to make a study about certain language, we should understand about the structural element of a language as human language, then we may extend the study up to the understanding of how the language is acquired and how the language used in real situation where many aspects of linguistics and non linguistics tied the interactions between the interlocutors.

e.g.

The word which may has 2 different meaning when the structure is different.

(1) Which of these bags is hers?

à as question word 
(2) The bag, which she bought yesterday, is expensive.

à as relative pronoun

From the above example, it can be seen that to be able to understand a certain construction or certain word, we should know that which has two different structural identities, the first is as a question word as in (1), and the later is as relative pronoun as in (2). Unless we have the knowledge of such structural properties, we will not be able to say that they have different meaning and this will results in misunderstanding.

\section{The ways to develop the theory of language structure}

Radford $(1988,1997)$ mentions at least two ways to develop the theory of language structure. They are as follow:

1. Formulate detailed descriptions of particular languages (known as grammar). It tells us how to 'speak' and 'understand' the language, then comprise a set of rules or principles, which specify how to form, pronounce, and interpret phrases, sentences in the language concerned.

2. Abstract from particular grammars common, universal properties that they all share: this is the study of Universal Grammar $(U G)$. Chomsky argued that the overall task of the linguist is to formulate grammar of particular languages and it became the point in proving the UG.

This is very much in line with what Chomsky said in the previous paragraph that it is very important to formulate the grammar of language studied so that we will be able to know specific characteristics of the structural elements of the language. Later on if the understanding of the language formulation is achieved, the study can be explored deeper by abstracting the particular formulas or grammars of particular language to UG so that we can infer such a generalization. 


\section{Grammar and level of adequacy}

Grammar of a language is a model of the linguistic competence of the fluent native speaker of the language. In Wikipedia Encyclopedia (2007), Chomsky made a distinction between grammars, which achieved descriptive adequacy, and those that went further and achieved explanatory adequacy. Radford (1988: 28) says that:

A grammar of a language is descriptively adequate if it correctly specifies which sentences are (and are not) syntactically, semantically, morphologically, and phonologically well-formed in the language, and also properly describes the syntactic, semantic, morphological, and phonological structure of the sentences in the language in such a way as to provide a principal account of the native speakers' intuition about this structure

It means that descriptively adequate grammar for a particular language defines the (infinite) set of grammatical sentences in that language; that is, it describes the language in its entirely (Wikipedia: 2007). On the other hand, a grammar that achieves explanatory adequacy has the additional property that gives an insight into the underlying linguistic structures in the human mind; that is, it does not merely describe the grammar of a language, but makes predictions about how linguistic knowledge is mentally represented. For Chomsky, the nature of such mental representations is largely innate, so if a grammatical theory has explanatory adequacy it must be able to explain the various grammatical nuances of the languages of the world as relatively minor variations in the universal pattern of human language.

Thus, he contrasted two different terms, namely competence (the fluent native speakers' knowledge of the language) and performance (what people actually 
say/understand by what someone else says on a given occasion).

a. Competence is the speaker-hearer's knowledge of his language b. Performance is the actual use of language in concrete situation

Chomsky distinguishes two types of competence: (1) grammatical competence, (2) pragmatic competence. The first belongs to Theory of Language Structure, and the second to the Theory of Language Use. Let's look at the following example:

\section{(3) She believes that Jeannie will come}

To the native speaker's grammatical competence (his knowledge of the grammar of his language), the word she cannot be interpreted as the same person as Jeannie, as the referent. Even, the pragmatic competence enables the speaker to bring non-linguistic information in interpreting the sentence.

Grammatical competence is divided into two; they are (1) intuition about sentence well formed-ness, (2) intuition about sentence structure. It is a kind of judgment whether a given sentence is well formed or not, and about whether it has a particular structure or not (Radford, 1988: 6).

(4) (a). THIS is a graMMatical SENtence

(b). * This is A grammatiCAL sentence (Radford, 1988: 4)

(5) (a). The teachers are having seminar now.

(b). * The mans are talking about the motor cars 
(6) (a). He is my husband

(b). * My wife is not my wife (Radford, 1988: 46)

(7) (a). The cat is on the mat

(b). * Mat the on is cat (Sampson, 1980: 133)

The above examples show sentences being grammatical and ungrammatical (ill formed). Sentence (4) (a) is phonologically well formed; however, (b) is ill formed, as the stress, which is shown by the capital letter, is put incorrectly. Sentence (5) (a) is morphologically well formed as the plural form of man is not * mans, as well as the regular form in (b) teacher, but it should be men. Sentence (6) (a) is semantically well formed as the object of $\mathrm{He}$ and my husband refers to the same person, however in (b), it is contradictory to the meaning by negation which stating that my wife reflects different person. The last is sentence (7) (a) which is syntactically well formed through its sequence; however (b) have incorrect sequence, which leads to its being ill formed.

From the above explanation, it can be inferred that Chomsky believed in that the form of language is genetically constrained, and the key to uncovering the nature of these constrain lies in the study of Universal Grammar.

Jacobs and Rosenbaum (1976: v) stated that linguistic universals determine the form of a complete and accurate representation of what human beings know when they know a language. These universal will provide the information necessary to know how the strategy by means of which human 
beings acquire a language in the very first time.

\section{Constituents}

There are two types of the structural intuitions which native speakers have about the Syntax, namely (1) intuition about how sound- sequences in sentences are structured into successively larger structural units which we call constituents; and (2) intuition about whether particular sets of constituents belong to the same category or not. Words belong o various categories of different types like Noun, Adjective, Adverb, Preposition, Modal, Determiner, etc. We can illustrate the nature of these intuitions about constituents and categories as in the following sentence:

(8) His teacher might get very angry to the student.

\section{Sentence}

Due to the first intuition about the way in which the words in (8) are grouped into successively larger constituents, the word his modifies teacher so that his teacher is a (phrasal) constituent of the sentence. Likewise, the goes with student, and forms a phrasal constituent as well the student. It is also clear that to goes with the student to make a larger constituent of to the student. Then very modifies angry so that the sequence of very angry forms a single structural unit, a constituent of a sentence. Furthermore, it is obvious that get goes with the phrase very angry so that get very angry is also a constituent. The larger constituent of a sentence which relates some smaller constituents are get very angry to the student. From the tree diagram above, every node represents a constituent both in the individual words and phrases.

The traditional way of describing the similarities and differences between constituents is to say that they belong to categories of various types. 
Therefore, words like teacher, student are said as category of Nouns, meanwhile the words like his, the belong to the category of Determiners. The word get is the same as appear, feel, become which belong to the category of Verb; and the word must is the same kind of constituents as may, must, will, etc which is said as Modal; the word very belongs to Adverb, and angry belongs to Adjective.

Constituency grammar could be defined intuitively as the kind of grammatical notation appropriate for languages where the criteria of grammaticality have too with class-membership and hierarchical structure Sampson, (1980: 139).

\section{Deep structure, surface structure, and transformations}

Chomsky then, in 1957, developed his explanation in Syntactic Structures that what he firstly believed that constituency grammar is adequate to generate human language is actually wrong. He also stated that constituent structure is not enough in helping the native speaker to understand grammatical sentences (Jacobs and Rosenbaum, 1976: 17). To argue that the model of syntax is not adequate to handle certain characteristic constructions in natural languages; therefore there should be an additional level of structure known as D-Structure (Radford , 1988: 401).

The two levels of structure (S-structure and D-structure) are inter- related by a set of movement rules called Transformations. Every sentence represents a deep structure and a surface structure. The deep structure represented the core semantic relations of a sentence, and was mapped on to the surface structure through transformations. Chomsky believed that there would be considerable similarities between languages' deep structures, and that these 
structures would reveal properties, common to all languages, which were concealed by their surface structures (Wikipedia,

2007). Sampson (1980: 140) defined the term of transformational rule as the following:

A transformational rule is a rule which operates on the hierarchical structure assigned to a morpheme sequence by a constituent grammar, and alters it into a new hierarchical structure in way which modifies the string of morphemes acting as levels of the tree.

In Transformational Generative Grammar, and then called as Transformational Linguistics Deep structures were generated by a set of phrase structure rules. Consider the following example:

(9) You will come here. (10) Will you come here?

The first sentence is a declarative sentence while the second is an interrogative sentence. The above sentences are very similar syntactically. They are different only on the position of two words only. It is said that the two sentences have different deep structure because they are different in meaning.

The following D-structure contains a constituent QUESTION, which does two things:

1. It specifies that the sentence is a question semantically.

2. It provides a structure upon which the interrogative transformation is defined and can apply.

Such transformation applies only if the QUESTION constituent is present, the grammar prevents the application of the transformation to Dstructure which is not semantically interpreted as question.

The interrogative transformation above generates the surface structure diagrammed below: 
It is also possible elaborate a negation through transformation process as in the following example:

(11) They will study Mathematics.

(12) They will not study Mathematics.

These two sentences are identical in their surface structure, except the negation in the second sentence. They have different deep structures. It can be elaborated through the hypothetical constituent NEGATIVE (NEG). The NEG gives information that even the rest of the structure is identical to (11), however, the meaning are different as it has negative interpretation. The negative transformation above generates the surface structure.

\section{Conclusion}

\section{Summary on the Transformational Process}

The implication of Universal Grammar in transformational process is that sentences of all languages have both a D-Structure, which gives the meaning of the sentence, and S- structure, which gives the form of the sentence when it is used in communication. It can be said that D-structure is abstract while Sstructure is closer to physical reality that give the concrete form of the syntactic structures used in communication.

The implication of transformational generative grammar towards the process of L2 learning

Dealing with the process of learning and acquisition, these two terms are different in case they are used to separate L1 acquisition from L2 learning. In learning L2, it is a conscious activity, while acquisition deals with unconscious one. in language acquisition the focus is on communication or 
reception of a message as opposed to syntax and grammar as in language learning.

In teaching English as L2, therefore knowing syntax and grammar of the language is important. Transformational Generative Grammar gives adequate elaboration in understanding them. Thus, the learners are expected to be able to avoid such ambiguity in interpreting the deep structure of a sentence since ambiguity will lead other people as the listeners or hearers of the speakers to misinterpret consciously or unconsciously.

\section{References}

Davis W. Philip. 1939. Modern Theories of Language. New Jersey: Prentice-Hall.Inc.

Jacobs and Rosenbaum.P. 1968. English Transformational Grammar. The United States of America: John Willey \&Sons.

Jackendoff, Ray (1974). Semantic Interpretation in Generative Grammar. MIT Press.

Radford. A. 1988. Transformational Grammar. Cambridge: Cambridge University Press.

Sampson. G. 1980. Schools of Linguistics: Competition and Evolution. Great Britain: British Library. Wikipedia Free Encyclopedia. 2007. 